\title{
FORECASTING MODAL SENDIRI, MODAL PINJAMAN, DAN SHU (SISA HASIL USAHA) PADA KOPERASI GANESA STUDI GRUP SINGARAJA TAHUN 2018
}

\author{
Nita zilviah sari \\ Jurusan Pendidikan Ekonomi \\ Universitas Pendidikan Ganesha \\ Singaraja, Indonesia \\ e-mail: nithazilviahsari@yahoo.com
}

\begin{abstract}
Abstrak
Penelitian ini bertujuan untuk mengetahui forecasting modal sendiri, modal pinjaman, dan SHU (Sisa Hasil Usaha) pada Koperasi Ganesa Studi Grup tahun 2018. Jenis data dalam penelitian ini merupakan data kuantitatif yaitu berupa laporan neraca dan laporan keuangan Koperasi Ganesa Studi Grup Tahun 2011 s.d Tahun 2017. Metode pengumpulan dalam penelitian ini menggunakan dokumentasi. Metode analisis data menggunakan trend dengan metode least square. Hasil penelitian menunjukkan bahwa Forecasting Modal Sendiri, Modal Pinjaman dan SHU di Koperasi Ganesa Studi Grup pada Tahun 2018 menggunakan trend dengan metode least square didapatkan hasil modal sendiri pada tahun 2018 mengalami penurunan dari tahun sebelumnya yaitu sebesar $R p$ 260.880.591,44 sedangkan modal pinjaman mengalami peningkatan dari tahun sebelumnya yaitu sebesar $R p$ 387.237.605,26 dan SHU pada tahun 2018 mengalami peningkatan sebesar Rp 24.538.742,6.
\end{abstract}

Kata kunci : modal sendiri, modal pinjama, SHU

\begin{abstract}
This study aims to know forecasting own capital, loan capital, and SHU (the remaining results of operations) in Koperasi Ganesa Studi Grup in 2018. The type of data in this study is quantitative data in the form of balance sheet and financial report Koperasi Ganesa Studi Grup 2011 up to 2017. Methods of data collection in this study using documentation. Data analysis method using trend with least square method. The results showed that Forecasting of Own Capital, Loan Capital and SHU (the remaining results of operations) in Koperasi Ganesa Studi Grup Singaraja in 2018. using the trend with the least square method obtained the results of its own capital in 2018 decreased from the previous year which amounted to $\mathrm{Rp}$ $260.880 .591,44$ while loan capital has increased from the previous year which amounted to $R p$ 387.237.605,26 and SHU in 2018 increased by Rp 24.538.742,6.
\end{abstract}

Keywords: own capital, capital loans, SHU

\section{PENDAHULUAN}

Koperasi merupakan salah satu kekuatan ekonomi yang tumbuh di kalangan masyarakat sebagai pendorong tumbuhnya perekonomian nasional sekaligus sebagai soko guru dalam perekonomian Negara Indonesia.

Menurut UU No. 25 Tahun 1992 tentang perkoperasian Bab I Pasal I Koperasi adalah " Badan usaha yang beranggotakan orang seorang atau badan hukum koperasi dengan melandaskan kegiatannya berdasarkan prinsip koperasi sebagai gerakan ekonomi rakyat yang berdasarkan atas azas kekeluargaan". Koperasi tidak mengutamakan "keuntungan", dikarenakan kegiatan usaha di dalam koperasi bukan semata-mata mencari keuntungan (non profit oriented) tetapi berorientasi pada manfaat (benefit 
oriented). Koperasi pada dasarnya dikelola dengan tujuan untuk mensejahterakan anggotanya dan masyarakat pada umumnya, bukan mengejar untung semata. Walaupun koperasi tidak mengutamakan keuntungan, akan tetapi usaha yang dikelola koperasi harus memperoleh penghasilan yang layak demi menjaga kelangsungan hidup dan meningkatkan kemampuan usaha. Demi menjaga kelangsungan hidup dan meningkatkan kemampuan usaha ini, koperasi memerlukan modal untuk menjaga dan meningkatkan usaha koperasi. Karena di akhir periode nanti usaha koperasi diharapkan dan ditargetkan untuk menghasilkan Sisa Hasil Usaha (SHU). Keuntungan didalam koperasi biasa disebut dengan istilah SHU. Berdasarkan UU No.25 Tahun 1992 Pasal 45 Ayat 1 "Sisa Hasil Usaha merupakan pendapatan koperasi yang diperoleh dalam waktu satu tahun buku dikurangi dengan biaya, penyusutan, dan kewajiban lainnya termasuk pajak dalam tahun buku yang bersangkutan".

Sebagai badan usaha, pendapatan atau hasil usaha sangat menentukan besar kecilnya SHU yang diperoleh koperasi. Dalam setiap tahunnya SHU yang diperoleh koperasi disisihkan dan dibagi untuk keperluan: cadangan koperasi, jasa anggota, dana pengurus, dana karyawan, dana pendidikkan, dana sosial dan dana pembangunan daerah kerja. Melalui SHU koperasi dapat memupuk modal sendiri yaitu dengan dana cadangan yang disisihkan setiap akhir periode tutup buku, sehingga akan memperkuat struktur modalnya. Selain itu dana-dana yang disisihkan dari SHU, apabila belum dicairkan atau digunakan maka akan diperlakukan sebagai tambahan modal yaitu sebagai modal pinjaman tanpa dikenakan biaya modal. Oleh sebab itu apabila koperasi dapat meningkatkan perolehan SHU dalam setiap tahunnya dengan sendirinya akan memperkuat struktur modalnya.

Menurut Sitio \& Halomoan (2001:79), "Semakin tinggi partisipasi anggota maka idealnya semakin tinggi manfaat yang diterima anggota". Partisipasi anggota adalah partisipasi modal berupa modal sendiri dan transaksi yang dilakukan anggota. Apabila semakin besar modal sendiri yang disetor, maka akan semakin besar pada keleluasaan para anggotanya dalam beroperasi untuk meningkatkan volume usahanya sehingga hal ini tentunya akan meningkatkan SHU yang dapat diperoleh pihak koperasi. Dengan demikian dapat dikatakan bahwa modal sendiri berpengaruh tehadap perolehan SHU. Semakin besar modal sendiri yang disetor diharapkan koperasi dapat memperoleh $\mathrm{SHU}$ yang besar pula.

Menurut UU No. 25 tahun 1992 Pasal 41 ayat 1 "Modal koperasi terdiri dari modal sendiri dan modal pinjaman". UU No. 25 tahun 1992 Pasal 41 ayat 2 "Modal sendiri dapat berasal dari: simpanan pokok, simpanan wajib, dana cadangan dan hibah". UU No. 25 tahun 1992 Pasal 41 ayat 3 "Modal pinjaman dapat berasal dari : anggota, koperasi lainnya dan atau anggotanya, bank dan lembaga keuangan lainnya, penerbitan obligasi dan surat hutang lainnya, serta sumber lainnya yang sah".

Riyanto (2001:23) beranggapan bahwa pembelanjaan yang sehat itu pertama-tama dibangun atas dasar modal sendiri, yaitu modal tahan resiko. Maka aturan dalam struktur finansial menetapkan bahwa besarnya modal asing dalam keadaan bagaimanapun juga tidak boleh melebihi besarnya modal sendiri. Struktur finansial tersebut akan memperlihatkan dengan jelas modal yang dimiliki.

Koperasi Ganesa Studi Grup merupakan salah satu contoh koperasi simpan pinjam yang ada di Singaraja. Seperti koperasi pada umumnya, koperasi ini juga bertujuan untuk meningkatkan kesejahteraan anggotanya melalui kegiatan operasionalnya. Setiap koperasi juga menargetkan keuntungan yang ingin dicapai setiap tahunnya. Keuntungan yang diperoleh koperasi disebut dengan Sisa Hasil Usaha (SHU). SHU pada koperasi Ganesa Studi Grup tidak mengalami peningkatan setiap tahunnya. 
Tabel 1. Modal sendiri, modal pinjaman dan SHU Koperasi Ganesa Studi Grup tahun 2011 s.d. tahun 2017

\begin{tabular}{|c|c|c|c|c|}
\hline \multirow{2}{*}{ Tahun } & Modal Sendiri & Modal Pinjaman & Jumlah & $\mathrm{SHU}$ \\
\hline & $(\operatorname{Rp} 0,00)$ & $(\operatorname{Rp} 0,00)$ & $(\operatorname{Rp} 0,00)$ & $(\operatorname{Rp} 0,00)$ \\
\hline $\begin{array}{l}2011 \\
2012\end{array}$ & $\begin{array}{l}125.797 .683 \\
143.711 .341\end{array}$ & - & $\begin{array}{l}125.797 .683 \\
143.711 .341\end{array}$ & $\begin{array}{l}12.046 .923 \\
10.898 .106\end{array}$ \\
\hline 2013 & 176.901.341 & - & 176.901.341 & 12.496 .066 \\
\hline 2014 & 181.430 .541 & - & 181.430 .541 & 18.643 .912 \\
\hline 2015 & 202.384 .454 & 311.643 .793 & 514.028 .247 & 20.521 .555 \\
\hline 2016 & 220.806 .200 & 294.651 .893 & 515.458 .093 & 21.938 .937 \\
\hline 2017 & $298.309 .313,06$ & 300.854 .993 & $599.164 .306,06$ & $22.117 .012,74$ \\
\hline
\end{tabular}

tabel 1 di atas dapat terlihat bahwa modal sendiri setiap tahunnya mengalami peningkatan, modal pinjaman mengalami penurunan pada tahun 2016 dan SHU (Sisa Hasil Usaha) pada tahun 2012 mengalami penurunan sedangkan dari tahun 2013 sampai 2016 mengalami peningkatan.

Hal ini tidak sejalan dengan pendapat Sitio \& Halomoan (2001:79), "Semakin tinggi partisipasi anggota maka idealnya semakin tinggi manfaat yang diterima anggota". Partisipasi anggota adalah partisipasi modal berupa modal sendiri dan transaksi yang dilakukan anggota. Semakin besar modal sendiri yang disetor diharapkan koperasi dapat memperoleh SHU yang besar pula. Penurunan yang terjadi pada modal pinjaman dan SHU pada Koperasi Ganesa Studi Grup dapat menyebabkan ketidakstabilan pada koperasi, untuk menghindari ketidakstabilan tersebut perlu diadakannya forecasting (peramalan).

Koperasi memerlukan forecasting (ramalan) yaitu dapat dicari dengan menggunakan trend untuk memperkirakan berapa jumlah keuntungan yang kemungkinan terjadi ditahun yang akan datang. Dengan demikian, koperasi dapat membuat suatu tindakan, kebijakan, atau keputusan yang dilakukan secara tepat untuk mencapai target tersebut.

Pengertian forecasting adalah seni dan ilmu untuk memperkirakan kejadian di masa depan. Hal ini dapat dilakukan dengan melibatkan pengambilan data masa lalu dan menempatkannya ke masa yang akan datang dengan suatu bentuk model matematis.

Fungsi peramalan atau forecasting terlihat pada saat pengambilan keputusan.
Keputusan yang baik ialah keputusan yang didasarkan atas pertimbangan apa yang akan terjadi pada waktu keputusan itu dilaksanakan. Apabila kurang tepat ramalan yang kita susun, maka masalah peramalan juga merupakan masalah yang selalu kita hadapi (Ginting, 2007).

Menurut Ginting (2007) berdasarkan sifat penyusunannya, peramalan dibagi menjadi dua jenis sebagai berikut. Pertama peramalan subjektif yaitu peramalan yang didasarkan atas perasaan atau intuisi dari orang yang menyusunnya.; Kedua peramalan objektif yaitu peramalan yang didasarkan atas data yang relevan pada masa lalu dengan menggunakan teknikteknik dan metode-metode dalam penganalisaan data tersebut.

Widiyanti (2003:1) "koperasi adalah suatu perkumpulan yang beranggotakan orang-orang atau badan-badan, yang memberikan kebebasan masuk dan keluar anggota dengan kerjasama secara kekeluargaan menjalankan usaha, untuk mempertinggi kesejahteraan jasmaniah para anggotanya".

Pengertian koperasi menurut Undang-undang Perkoperasian No.25 tahun 1992, yaitu: "Badan usaha yang beranggotakan orang seorang atau badan hukum koperasi dengan berlandaskan kegiatan pada prinsip koperasi sekaligus sebagai gerakan ekonomi rakyat yang berdasar atas azas kekeluargaan.Ada beberapa definisi dari koperasi yang dikemukakan oleh para pakar ekonomi. Dalam UU No. 25 Bab II Pasal 3 Tahun 1992 menyebutkan bahwa, "Koperasi bertujuan memajukan kesejahteraan anggota pada khususnya dan masyarakat pada umumnya serta ikut membangun tatanan perekonomian nasional dalam 
rangka mewujudkan masyarakat maju, adil dan makmur berdasarkan Pancasila dan Undang-Undang Dasar 1945".

Menururt Widiyanti (2003) prinsipprinsip koperasi adalah sebagai berikut: Pengelolaan oleh anggota secara demokratis, Keanggotaan bersifat sukarela dan terbuka, Pembatasan bunga atas modal, Sisa Hasil Usaha dibagi kepada para anggota sebanding dengan jumlah jasa mereka di koperasi, Menyelenggarakan kegiatan pendidikan secara teratur dan terus-menerus bagi para anggotanya untuk memelihara semangat koperasi dan perkembangan koperasi, Netral terhadap agama dan politik, Kerjasama antar koperasi.

Dalam UU No. 25 tahun 1992 tentang perkoperasian, pasal 41 , ayat VII, disebutkan bahwa Modal Koperasi terdiri dari: modal sendiri dan modal pinjaman. Menurut Riyanto (2001:240) Modal sendiri pada dasarnya adalah modal yang berasal dari pemilik perusahaan yang tertanam di dalam perusahaan untuk waktu yang tidak tertentu lamanya. Secara lebih rinci Sitio \& Halomoan (2001:84) mengatakan "Modal sendiri bersumber dari simpanan pokok anggota, simpanan wajib, dana cadangan, dan donasi atau hibah". Hendar \& Kusnadi (2002:275) menyatakan bahwa Modal anggota adalah simpanan pokok dan wajib yang harus dibayar anggota kepada koperasi sesuai dengan ketentuan yang berlaku pada koperasi, tiap anggota memiliki hak suara yang sama. Tidak tergantung pada besarnya modal anggota pada koperasi.

Lebih lanjut di jelaskan oleh Pachta, dkk (2005:117) tentang modal sendiri adalah "Modal sendiri adalah modal yang berasal dari dana pendiri atau anggota koperasi yang disetorkan pertama kali; dalam bahas teknis organisasi perusahaan biasanya disebut sebagai modal dasar pendirian koperasi”.

Menurut Pachta, dkk (2008:122) pada prinsipnya modal koperasi dapat berasal dari mana saja dan dapat berupa uang atau barang, sepanjang pinjaman tersebut digunakan untuk mengembangkan usaha koperasi. Setiap koperasi menerima pinjaman dari pihak manapun, sangat penting membuat perjanjian secara tertulis setiap transaksi pinjaman yang dilakukan oleh koperasi dan pentingnya untuk mengatur secara detail mengenai syarat dan ketentuan penerimaan pinjaman dalam Anggaran Dasar dan Anggaran Rumah Tangga koperasi sehingga dapat menjadi pedoman bagi pengurus dalam menerima pinjaman tanpa merugikan koperasi.

Menurut Pachta, dkk $(2005: 128,133)$

$\mathrm{SHU}$ adalah merupakan laba atau keuntungan yang diperoleh dari menjalankan usaha sebagaimana layaknya sebuah perusahaan bukan koperasi. SHU tersebut merupakan hasil akhir dari komponen-komponen yang menghasilkan dikurangi dengan jumlah komponenkomponen biaya. Arifin Sitio dan Halomoan Tamba (2001:87) ditinjau dari aspek ekonomi manajerial, Sisa Hasil Usaha (SHU) koperasi adalah selisih dari seluruh pemasukan atau penerimaan total (total revenue) dengan biaya-biaya atau biaya total (total cost) dalam satu tahun buku.

Menurut Undang-Undang No.25

Tahun 1992 tentang Perkoperasian Bab IX Pasal 45 dinyatakan sebagai berikut. Pertama Sisa hasil usaha koperasi merupakan pendapatan koperasi yang diperoleh dalam satu tahun buku dikurangi dengan biaya, penyusutan, dan kewajiban lannya termasuk pajak dalam tahun buku yang bersangkutan.; Kedua Sisa hasil usaha setelah dikurangi dana cadangan dan dana-dana lain dibagikan kepada anggota dan pegawai sebanding dengan jasa usaha yang dilakukan oleh masingmasing anggota dengan koperasi, serta digunakan untuk keperluan pendidikan perkoperasian dan keperluan lain dari koperasi sesuai dengan keputusan Rapat Anggota.

Faktor-faktor yang mempengaruhi SHU (Sisa Hasil Usaha) Menurut Pachta, dkk (2005:56) "faktor-faktor yang mempengaruhi SHU terdiri dari dua faktor yaitu faktor dalam yang terdiri dari: Pertama Partisipasi Anggota yaitu para anggota koperasi harus berpartisipasi dalam kegiatan koperasi karena tanpa adanya peran anggota maka koperasi tidak akan berjalan lancar. Kedua Jumlah modal sendiri yaitu SHU anggota yang diperoleh sebagian dari modal sendiri yaitu dari simpanan wajib, simpanan pokok, dana 
cadangan dan hibah. Ketiga Kinerja pengurus sangat diperlukan dalam semua kegiatan yang di lakukan oleh koperasi, dengan adanya kinerja yang baik dan sesuai persyaratan dalam anggaran dasar serta UU Perkoperasian maka hasil yang di capaipun juga akan baik. keempat Jumlah unit usaha yang dimiliki yaitu Setiap koperasi pasti memiliki unit usaha hal ini juga menentukan seberapa besar volume usaha yang di jalankan dalam kegiatan usaha tersebut. Kelima Kinerja manajer menentukan jalannya semua kegiatan yang dilakukan oleh koperasi dan memiliki wewenang atas semua hal-hal yang bersifat intern.; keenam Kinerja karyawan Merupakan kemampuan seorang karyawan dalam menjadi anggota koperasi. Faktor dari luar yang terdiri dari: modal pinjaman dari luar, para konsumen dari luar selain anggota koperasi, pemerintah, Kekayaan koperasi yang merupakan pemberian bantuan kepada pihak koperasi secara sukarela baik berwujud uang maupun barang biasanya berasal dari pemerintah dan merupakan hibah.

Penelitian ini bertujuan untuk mengetahui Forecasting (ramalan) modal sendiri, modal pinjaman, dan sisa hasil usaha (SHU) pada Koperasi Ganesa Studi Grup Tahun 2018.

\section{METODE}

Jenis data yang digunakan dalam penelitian ini adalah data kuantitatif yaitu laporan neraca dan laporan keuangan SHU tahun 2011 - 2017, data tentang modal sendiri, modal pinjaman, dan SHU. Sumber data dalam penelitian ini adalah data sekunder yaitu data yang diproleh dari laporan tahunan di Koperasi Ganesa Studi Grup berupa neraca dan laporan SHU periode pelaporan 2011 - 2017. Data tersebut akan diambil dan dikumpulkan dengan metode dokumentasi. Dalam hal ini data yang didokumentasikan adalah data yang berkaitan dengan neraca dan laporan SHU Koperasi Ganesa Studi Grup Tahun 2011- 2017.

Analisis yang digunakan dalam penelitian ini adalah analisis deskriptif kuantitatif, yaitu suatu metode yang bersifat penjelasan dan keterangan dalam bentuk angka-angka dan tabel yang mendeskripsikan kembali apa yang diperoleh di lapangan dalam bentuk paparan statistik, sehingga peneliti hanya menggambarkan seluruh peristiwa yang terjadi di lapangan dalam bentuk kuantitatif (angka) saja dengan cara menghitung garis tren modal sendiri, modal pinjaman dan sisa hasil usaha (SHU) yang terjadi 7 tahun terakhir.

Metode yang digunakan dalam analisis data yaitu trend. Trend adalah salah satu peralatan statistik yang dapat digunakan untuk memperkirakan keadaan dimasa yang akan datang berdasarkan pada data masa lalu. Misalnya, modal sendiri yang direncanakan didasarkan pada perkembangan simpanan pokok,simpanan wajib, dana cadangan dan hibah. Kejadian pada masa akan datang sebenarnya tidak jauh berbeda dengan kejadian masa lalu, hanya saja dalam hal ini perlu diadakan penyesuaian dengan berbagai independent variable. Kita juga menyadari tidak semua peristiwa di masa yang lampau akan terjadi secara tepat pada masa yang akan datang, tetapi beberapa ketentuan dan pola - pola tertentu tidak jauh berbeda dengan masa lalu. Berdasarkan pada uraian ini pula, penulis menggunakan trend sebagai alat proyeksi untuk memperkirakan tentang modal sendiri,modal pinjaman dan SHU dari berbagai kegiatan di masa yang akan datang.

Trend sebenarnya adalah gerakan dari data deret berkala selama beberapa tahun dan cenderung menuju pada suatu arah, di mana arahnya bisa naik, mendatar, maupun menurun. Bentuk trend terdiri dari trend linier dan nonlinier. Metode perhitungan trend linier pada umumnya terdiri dari least square method, freehand method, semiaverage method, dan moving average method. Penulis dalam penelitian ini hanya menggunakan trend linier dengan menggunakan metode least square. Metode jumlah kuadrat terkecil atau metode least quare (least square's method) adalah jumlah kuadran penyimpangan (deviasi) nilai data terhadap garis tren minimum atau terkecil (Noegroho Boedijoewono, 2007:231). Ciri dari metode ini, yaitu dalam menentukan parameter $X$. Setelah parameter $X$ terbentuk dan dijumlah, 
jumlahnya harus 0 , walaupun dalam data historis berjumlah ganjil maupun data historis berjumlah genap.Cara menghitung dalam hal ini terhadap data dilakukan pembagian menjadi dua kelompok untuk

data yang jumlahnya: pertama Genap, maka skor nilai X-nya adalah .....-5, -3, -1, 1, 3, 5.; kedua Ganjil, maka skor nilai X-nya adalah ..... -2, $-1,0,1,2$

Bentuk persamaan trend dengan menggunakan metode least square dijabarkan sebagai berikut.

$Y_{c}=a+b(X)$

Dimana :

$\mathrm{Y}=$ Nilai yang diperkirakan

$a, b=$ Nilai konstanta dancoefecient dalam sebuah persamaan trend.

$\mathrm{X}=$ serangkaian tahun yang pernah terjadi.
Rumus untuk mencari nilai a dan b adalah sebagai berikut.

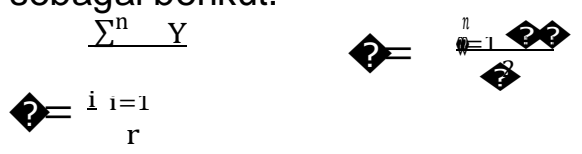

\section{HASIL DAN PEMBAHASAN}

Koperasi Ganesa Studi Grup merupakan salah satu koperasi simpan pinjam yang ada di kota Singaraja. Koperasi ini dibangun dengan tujuan untuk meningkatkan kesejahteraan anggotanya melalui kegiatan operasionalnya. Anggota koperasi yang ingin meminjam uang atau kredit dapat melakukan transaksinya di Koperasi Ganesa Studi Grup. Anggota Koperasi Ganesa Studi Grup berjumlah 125 orang. Data modal sendiri, modal pinjaman, dan SHU Koperasi Ganesa Studi Grup Tahun 2011 - 2017 nampak dalam tabel

Tabel 2. Modal sendiri, modal pinjaman, dan SHU Koperasi Ganesa Studi Grup tahun 2011 s.d 2017

\begin{tabular}{ccccc}
\hline \multirow{2}{*}{ Tahun } & \multicolumn{1}{c}{ Modal Sendiri } & Modal Pinjaman & Jumlah & SHU \\
\cline { 2 - 5 } & $(\operatorname{Rp~0,00)}$ & $(\operatorname{Rp~} 0,00)$ & $(\operatorname{Rp~0,00)}$ & $(\operatorname{Rp~0,00)}$ \\
\hline 2011 & 125.797 .683 & - & 125.797 .683 & 12.046 .923 \\
2012 & 143.711 .341 & - & 143.711 .341 & 10.898 .106 \\
2013 & 176.901 .341 & - & 176.901 .341 & 12.496 .066 \\
2014 & 181.430 .541 & - & 181.430 .541 & 18.643 .912 \\
2015 & 202.384 .454 & 311.643 .793 & 514.028 .247 & 20.521 .555 \\
2016 & 220.806 .200 & 294.651 .893 & 515.458 .093 & 21.938 .937 \\
2017 & $298.309 .313,06$ & 300.854 .993 & $599.164 .306,06$ & $22.117 .012,74$ \\
\hline
\end{tabular}

Dalam kasus Koperasi Ganesa Studi Grup ini, metode forecast yang digunakan adalah trend linier dengan menggunakan metode least square. Pada cara ini berlaku anggapan bahwa apa yang terjadi pada masa mendatang tidak terlepas

dari apa yang terjadi pada masa yang lalu. Modal sendiri, modal pinjaman dan SHU tahun depan dapat dihitung berdasarkan pada modal sendiri, modal pinjaman dan SHU yang pernah terjadi. Modal sendiri nampak dalam tabel

Tabel 3. Perhitungan Modal sendiri tahun 2011 s.d 2017

\begin{tabular}{ccccc}
\hline \multirow{2}{*}{ Tahun } & $\mathrm{Y}$ & $\mathrm{X}$ & $\mathrm{XY}$ & \multirow{2}{*}{$\mathrm{X}^{2}$} \\
\cline { 2 - 4 } 2011 & 125.797 .683 & -3 & -377.393 .049 & 9 \\
2012 & 143.711 .341 & -2 & -287.422 .682 & 4 \\
2013 & 176.901 .341 & -1 & -176.901 .341 & 1 \\
2014 & 181.430 .541 & 0 & 0 & 0 \\
2015 & 202.384 .454 & 1 & 202.384 .454 & 1 \\
2016 & 220.806 .200 & 2 & 441.612 .400 & 4 \\
2017 & $298.309 .313,06$ & 3 & $894.927 .939,18$ & 9 \\
\hline Jumlah & $1.128 .956 .419,1$ & 0 & $697.207 .721,18$ & 28 \\
\hline
\end{tabular}

Untuk menghitung persamaan trend, konstanta a dan b dihitung sebagai berikut.

$$
\sum_{\mathrm{i}=1}^{\mathrm{i} Y}=\frac{1.128 .956 .4}{\frac{19.1}{7}}=161.279 .488,44
$$

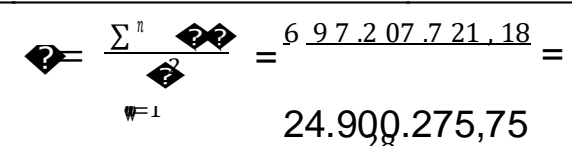

24.90Q.275,75

Persamaan trend : $Y_{c}=161.279 .488,44+$ 24.900.275,75 (x) 
Perkiraan modal sendiri $\left(Y_{c}\right)$ di Koperasi Ganesa Studi Grup dihitung dengan menggunakan trend dapat dilihat dalam tabel 4.

Tabel 4. Modal sendiri dihitung menggunakan trend tahun 2011 s.d. 2017

\begin{tabular}{|c|c|c|c|c|c|}
\hline \multirow{2}{*}{ Tahun } & $\mathrm{Y}$ & \multirow{2}{*}{$X$} & $X Y$ & \multirow{2}{*}{$X$} & $Y_{c}$ \\
\hline & $(\mathrm{Rp} 0,00)$ & & $(\mathrm{Rp} 0,00)$ & & $(\mathrm{Rp} 0,00)$ \\
\hline 2011 & 125.797 .683 & -3 & -377.393 .049 & 9 & $86.578 .661,19$ \\
\hline 2012 & 143.711 .341 & -2 & -287.422 .682 & 4 & $111.478 .936,94$ \\
\hline 2013 & 176.901 .341 & -1 & -176.901 .341 & 1 & $136.379 .212,69$ \\
\hline 2014 & 181.430 .541 & 0 & 0 & 0 & $161.279 .488,44$ \\
\hline 2015 & 202.384 .454 & 1 & 202.384 .454 & 1 & $186.179 .764,19$ \\
\hline 2016 & 220.806 .200 & 2 & 441.612 .400 & 4 & $211.080 .039,94$ \\
\hline 2017 & 298.309.313,06 & 3 & $894.927 .939,18$ & 9 & $235.980 .315,69$ \\
\hline Jumlah & $1.128 .956 .419,1$ & 0 & $697.207 .721,18$ & 28 & $1.128 .956 .419,1$ \\
\hline
\end{tabular}

sendiri pada tahun mendatang dengan menggunakan trend sebagai alat proyeksi perlu juga diketahui besarnya penyimpangan antara nilai proyeksi dengan data yang sebenarnya. Semakin besar angka penyimpangan, semakin besar kesalahan yang terjadi dalam penyi ipangan ierupal an suatu pertanda lebih baik menggunakan peralatan lainnya sebagai alat proyeksi. Cara untuk menghitung penyimpangan antara data trend dengan data sebenarnya dapat dilakukan sebagaimana dalam tabel 5 .

Tabel 5. Perhitungan penyimpangan modal sendiri antara data proyeksi dengan data sebenarnya

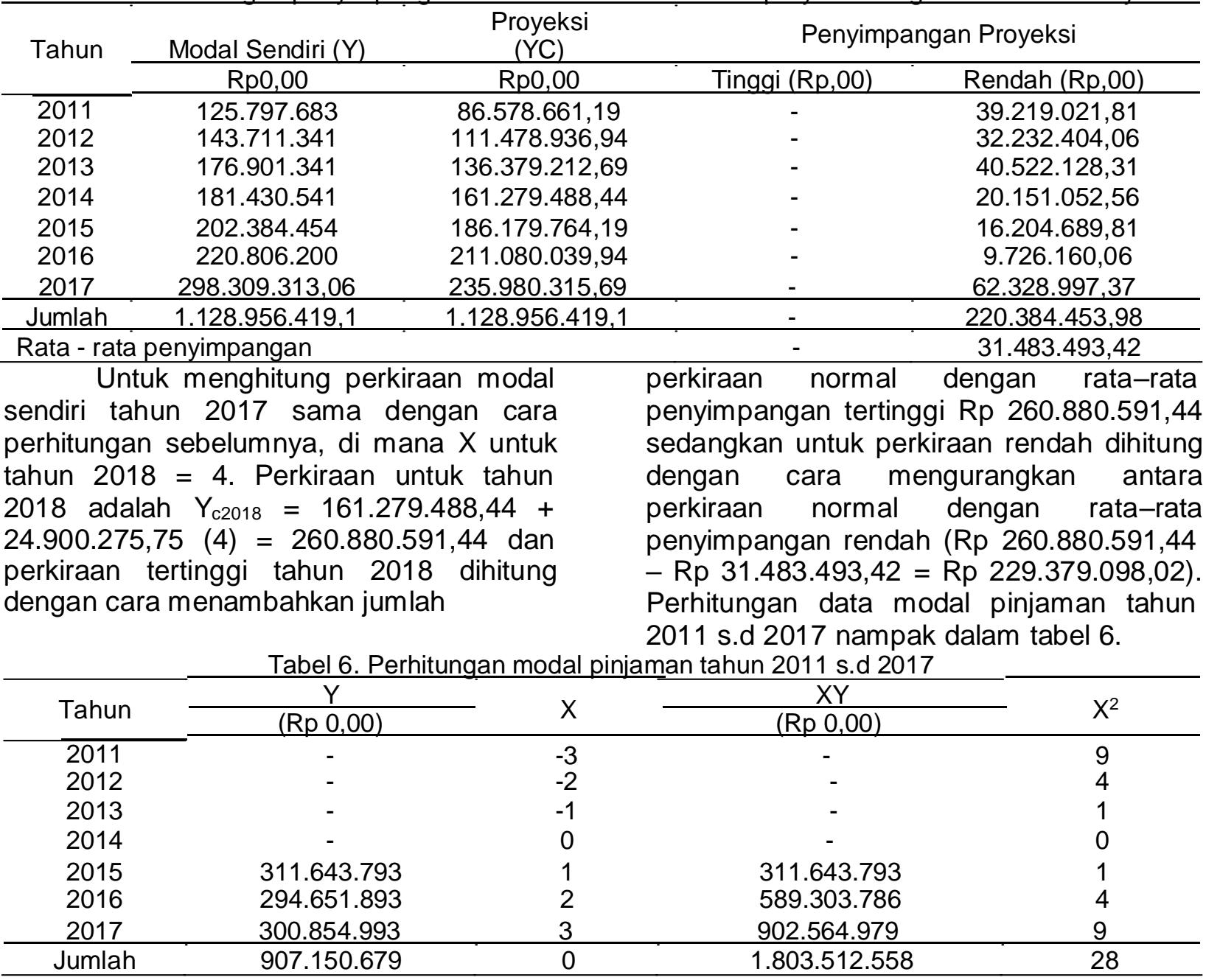


Untuk menghitung persamaan trend, konstanta $a$ dan $b$ dihitung dengan cara sebagai berikut:

$$
\begin{aligned}
& \sum_{i=1}^{n} Y=\frac{907.150 .6}{129.592 .954,14}
\end{aligned}
$$

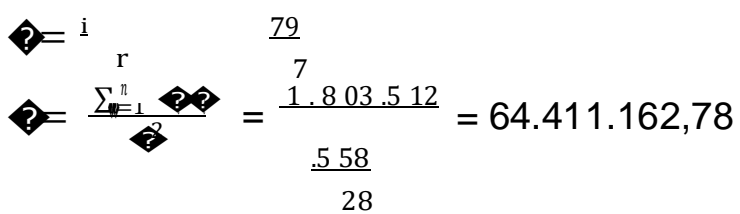

Persamaan trend : $Y_{c}=129.592 .954,14+$ 64.411.162,78 (x)

Perkiraan modal pinjaman $\left(Y_{c}\right)$ di Koperasi Ganesa Studi Grup dihitung dengan menggunakan trend dapat dilihat dalam

Tabel 7. Modal pinjaman dihitung menggunakan trend tahun 2011 s.d. 2017

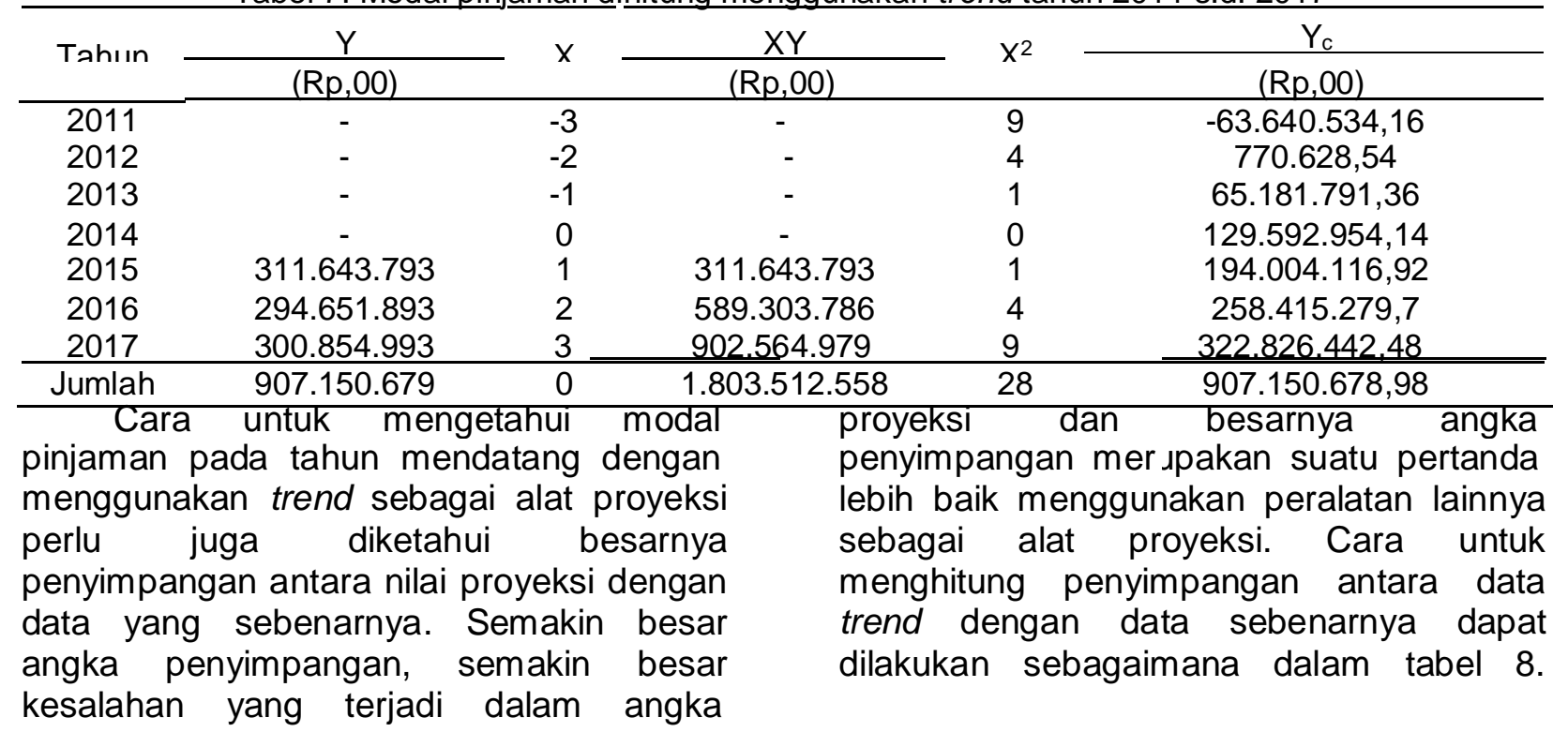

Tabel 8. Perhitungan penyimpangan modal pinjaman antara data proyeksi dengan data sebenarnya

\begin{tabular}{|c|c|c|c|c|}
\hline \multirow[t]{2}{*}{ Tahun } & \multirow{2}{*}{$\frac{\text { Modal pinjaman }(\mathrm{Y})}{(\mathrm{Rp} 0,00)}$} & \multirow{2}{*}{$\frac{\text { Proyeksi }\left(\mathrm{Y}_{\mathrm{c}}\right)}{(\mathrm{Rp} 0,00)}$} & \multicolumn{2}{|c|}{ Penyimpangan proyeksi } \\
\hline & & & Tinggi $(\mathrm{Rp} 0,00)$ & Rendah (Rp0,00) \\
\hline 2011 & - & -62.392 .922 & -62.392 .922 & - \\
\hline 2012 & - & $-16.040,8$ & $-16.040,8$ & - \\
\hline 2013 & - & $62.360 .840,4$ & $62.360 .840,4$ & - \\
\hline 2014 & - & $124.737 .721,6$ & $124.737 .721,6$ & - \\
\hline 2015 & 311.643 .793 & $187.114 .602,8$ & - & $124.529 .190,2$ \\
\hline 2016 & 249.651 .893 & 249.491 .484 & & 160.409 \\
\hline Jumlah & 561.295 .686 & 561.2 & 124.689 .599 & $124.689 .599,2$ \\
\hline \multicolumn{3}{|c|}{ Rata - rata penyimpangan } & 31.172 .400 & $62.344 .799,6$ \\
\hline \multicolumn{3}{|c|}{$\begin{array}{l}\text { Untuk menghitung perkiraan modal } \\
\text { pinjaman tahun } 2018 \text { sama dengan cara } \\
\text { perhitungan sebelumnya, di mana } X \text { untuk } \\
\text { tahun } 2018=4 . \text { Perkiraan untuk tahun } \\
2018 \text { adalah } \mathrm{Y}_{\mathrm{c} 2018}=129.592 .954,14+ \\
64.411 .162,78(4)=387.237 .605,26 \text { dan } \\
\text { perkiraan tertinggi tahun } 2018 \text { dihitung } \\
\text { dengan cara menambahkan jumlah }\end{array}$} & \multicolumn{2}{|c|}{$\begin{array}{l}\text { penyimpangan tertinggi }(\mathrm{Rp} 387.237 .605,26 \\
+\mathrm{Rp} 31.172 .400=\mathrm{Rp} 418.410 .005,26) \\
\text { sedangkan untuk perkiraan rendah dihitung } \\
\text { dengan cara mengurangkan antara } \\
\text { perkiraan normal dengan rata-rata } \\
\text { penyimpangan rendah (Rp } 387.237 .605,26 \\
\text { - Rp 62.344.799,6 = Rp 324.892.805,66 ). } \\
\text { Perhitungan SHU nampak dalam tabel 9. }\end{array}$} \\
\hline
\end{tabular}


Tabel 9. Perhitungan SHU (Sisa Hasil Usaha) tahun 2011 s.d 2017

\begin{tabular}{|c|c|c|c|c|}
\hline \multirow{2}{*}{ Tahun } & $Y$ & \multirow{2}{*}{$X$} & $X Y$ & \multirow{2}{*}{$X^{2}$} \\
\hline & $(\operatorname{Rp} 0.00)$ & & $(\mathrm{Rp} 0,00)$ & \\
\hline 2011 & 12.046 .923 & -3 & -36.140 .769 & 9 \\
\hline 2012 & 10.898 .106 & -2 & -21.796 .212 & 4 \\
\hline 2013 & 12.496 .066 & -1 & -12.496 .066 & 1 \\
\hline 2014 & 18.643 .912 & 0 & 0 & 0 \\
\hline 2015 & 20.521 .555 & 1 & 20.521 .555 & 1 \\
\hline 2016 & 21.938 .937 & 2 & 43.877 .874 & 4 \\
\hline 2017 & $22.117 .012,74$ & 3 & $66.351 .038,22$ & 9 \\
\hline Jumlah & $118.662 .511,74$ & 0 & $60.317 .420,22$ & 28 \\
\hline
\end{tabular}

Untuk menghitung persamaan trend, konstanta a dan $b$ dihitung dengan cara sebagai berikut:

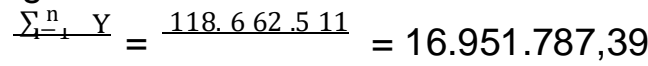

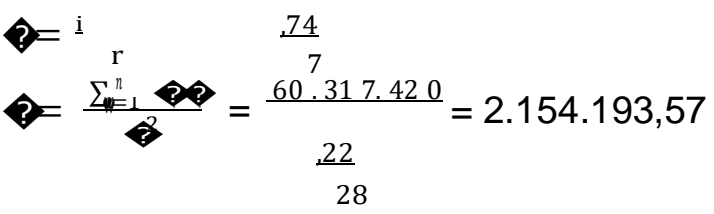

Tabel 10. SHU (Sisa Hasil Usaha) dihitung menggunakan trend tahun 2011 s.d. 2017

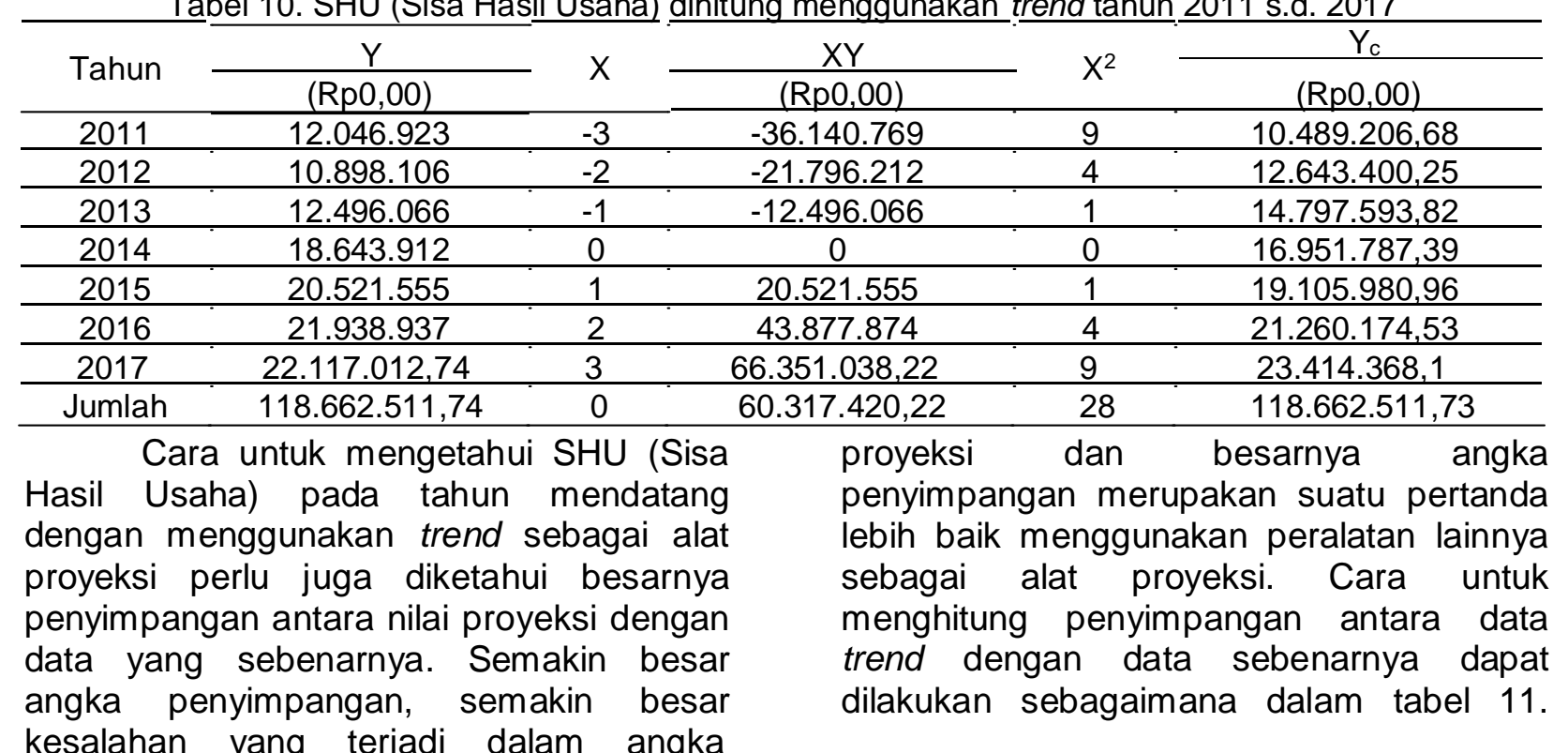

Persamaan trend : $Y_{c}=16.951 .787,39_{+}$ 2.154.193,57 (x)

Perkiraan SHU $\left(Y_{c}\right)$ di Koperasi Ganesa Studi Grup dihitung dengan menggunakan trend dapat dilihat dalam tabel 10. kesalahan yang terjadi dalam angka

Tabel 11. Perhitungan penyimpangan antara data proyeksi dengan data sebenarnya

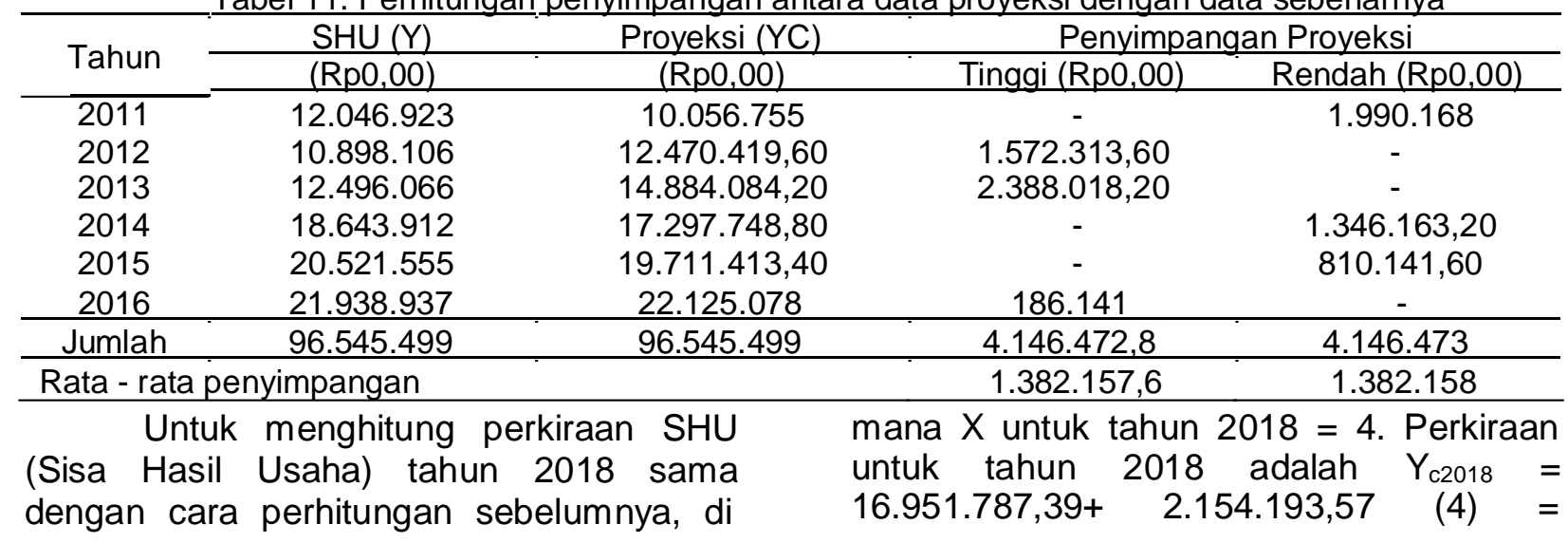


25.568.561,67 dan perkiraan tertinggi tahun 2018 dihitung dengan cara menambahkan jumlah perkiraan normal dengan rata - rata penyimpangan tertinggi ( $R p$ 25.568.561,67 $+\operatorname{Rp} 1.382 .157,6=\operatorname{Rp} 26.950 .719,27)$ sedangkan untuk perkiraan rendah dihitung dengan cara mengurangkan antara perkiraan normal dengan rata - rata penyimpangan rendah (Rp 25.568.561,67 Rp 1.382.158 = Rp 24.186.403,67).

Berdasarkan forecasting modal sendiri Koperasi Ganesa Studi Grup pada tahun 2018 mengalami penurunan dari tahun sebelumnya yaitu sebesar $R p$ $260.880 .591,44$. Temuan ini tidak sesuai dengan teori yang dikemukakan oleh Riyanto (2001:23) "beranggapan bahwa pembelanjaan yang sehat itu pertama-tama dibangun atas dasar modal sendiri, yaitu modal tahan resiko". Jika modal sendiri mengalami penurunan, maka dikhawatirkan dapat menimbulkan resiko yang dapat merugikan koperasi. Hal ini berarti Koperasi Ganesa Studi Grup harus bisa menyeimbangkan modal sendiri yang dimilikinya.

Modal pinjaman merupakan modal lain di luar modal sendiri yang diperoleh dari anggota, koperasi lain dan bank atau lembaga keuangan lainnya. Modal pinjaman digunakan untuk tambahan modal ketika modal sendiri yang dimiliki oleh koperasi kurang memenuhi. Modal pinjaman merupakan sejumlah uang dengan nilai tertentu yang diperoleh dari luar koperasi atas dasar perjanjian hutang antara koperasi dan pihak yang bersangkutan. Forecasting modal pinjaman Koperasi Ganesa Studi Grup pada tahun 2018 mengalami peningkatan dari tahun seblumnya sebesar Rp 387.237.605,26. Temuan ini juga tidak sesuai degan teori yang dikatakan Riyanto (2001:23) beranggapan bahwa pembelanjaan yang sehat itu pertama-tama dibangun atas dasar modal sendiri, yaitu modal tahan resiko. Maka aturan dalam struktur finansial menetapkan bahwa besarnya modal asing dalam keadaan bagaimanapun juga tidak boleh melebihi besarnya modal sendiri. Struktur finansial tersebut akan memperlihatkan dengan jelas modal yang dimiliki. Dari hasil yang didapat terlihat bahwa modal pinjaman tahun 2018 lebih besar dibandingkan dengan modal sendiri tahun 2018.

Berdasarkan UU No.25 Tahun 1992 Pasal 45 Ayat 1 "Sisa Hasil Usaha merupakan pendapatan koperasi yang diperoleh dalam waktu satu tahun buku dikurangi dengan biaya, penyusutan, dan kewajiban lainnya termasuk pajak dalam tahun buku yang bersangkutan". SHU Koperasi Ganesa Studi Grup pada tahun 2018 mengalami peningkatan dari tahun sebelumnya yaitu sebesar Rp. 25.568.561,67. Hal ini sesuai dengan teori yang dikatakan oleh Sitio \& Halomoan (2001:79), "Semakin tinggi partisipasi anggota maka idealnya semakin tinggi manfaat yang diterima anggota". Partisipasi anggota adalah partisipasi modal berupa modal sendiri dan transaksi yang dilakukan anggota. Apabila semakin besar modal sendiri yang disetor, maka akan semakin besar pada keleluasaan para anggotanya dalam beroperasi untuk meningkatkan volume usahanya sehingga hal ini tentunya akan meningkatkan SHU yang dapat diperoleh pihak koperasi. Dengan demikian dapat dikatakan bahwa modal sendiri berpengaruh tehadap perolehan SHU. Semakin besar modal sendiri yang disetor diharapkan koperasi dapat memperoleh SHU yang besar pula.

Dari peramalan yang telah dilakukan dapat dilihat bahwa modal sendiri mengalami penurunan, modal pinjaman mengalami peningkatan, dan SHU (Sisa Hasil Usaha) juga meningkat dari tahun sebelumnya. Adanya batas-batas perkiraaan yang dibentuk berdasarkan pada data penyimpangan, koperasi dapat mengadakan perkiraan secara lebih realistis dalam batas-batas yang telah ditetapkan sesuai dengan kondisi di masa yang akan datang.

\section{SIMPULAN DAN SARAN Simpulan}

Forecasting Modal sendiri, modal pinjaman dan SHU di Koperasi Ganesa Studi Grup pada tahun 2018 menggunakan trend dengan metode least square didapatkan hasil modal sendiri pada tahun 2018 mengalami penurunan dari tahun sebelumnya yaitu sebesar $R p$ 260.880.591,44 sedangkan modal pinjaman 
mengalami peningkatan dari tahun sebelumnya yaitu sebesar $R p$ 387.237.605,26 dan SHU pada tahun 2018 mengalami peningkatan sebesar 24.538.742,6.

\section{Saran}

Pertama untuk Koperasi Ganesa Studi Grup, berkaitan dengan modal sendiri hendaknya berusaha mengajak para anggotanya untuk menaikkan besarnya simpanan pokok dan simpanan wajib, sehingga dapat meningkatkan jumlah modal sendiri di koperasi tersebut. Mengingat bahwa bila modal sendiri lebih besar daripada modal pinjaman berarti koperasi tersebut dalam keadaan membaik. Berkaitan dengan modal pinjaman hendaknya perlu adanya pembinaan dalam modal pinjaman sehingga dapat digunakan untuk pengembangan usaha secara efisien dan efektif untuk memperoleh SHU yang maksimal. Kedua Untuk peneliti selanjutnya diharapkan dapat mengembangkan penelitian ini dengan cara mengkaji atau menambahkan variabel lain yang mempunyai peran penting dalam meningkatkan perolehan SHU, di luar modal sendiri dan modal pinjaman.

\section{DAFTAR PUSTAKA}

Ginting, Rosnani. 2007. Sistem Produksi. Yogyakarta: Graha IImu.

Hendar \& Kusnadi. 2002. Ekonomi Koperasi. Jakarta: Raja Grafindo Persada.

2005. Koperasi Indonesia : Edisi Kedua. Jakarta: Lembaga Penerbit Fakultas Ekonomi Universitas Indonesia.

Ibrahim, Yacob. 2009. Studi Kelayakan Bisnis. Jakarta: Rineka Cipta.

Boedijoewono, Nugroho. 2007. Pengantar Statistika Ekonomi dan Bisnis : Edisi Kelima. Yogyakarta: Unit Penerbit dan Percetakan AMP YKPN.

Pachta Andjar, Myra Rosana Bachtiar, Nadia Maulisa Benemy. 2005. Manajemen Koperasi, Teori dan praktek, Graha IImu. Jakarta: Kencana Prenada Media Group. 2008. Hukum Koperasi Indonesia: Pemahaman,

Regulasi,
Pendirian,dan Modal Usaha.

Jakarta: Kencana Prenada Media Group.

Riyanto, Bambang. 2001. Dasar-Dasar Pembelanjaan Perusahaan. Yogyakarta: Edisi Empat

Sitio, Arifin dan Halomoan Tamba 2001. Koperasi : Teori dan Praktik. Jakarta: Erlangga.

Undang - undang No. 25 tahun 1992 tentang perkoperasian.

Widiyanti, Ninik. 2003. Koperasi dan Perekonomian Indonesia, Jakarta: PT. Rineka Cipta. 